\title{
Magnetic Nanomaterials for Magnetically-Aided Drug Delivery and Hyperthermia
}

\author{
Madumali Kalubowilage, Katharine Janik and Stefan H. Bossmann *(i) \\ Department of Chemistry, Kansas State University, 201 CBC Building, Manhattan, KS 66506-0401, USA \\ * Correspondence: sbossman@ksu.edu
}

Received: 31 May 2019; Accepted: 11 July 2019; Published: 22 July 2019

\begin{abstract}
Magnetic nanoparticles have continuously gained importance for the purpose of magnetically-aided drug-delivery, magnetofection, and hyperthermia. We have summarized significant experimental approaches, as well as their advantages and disadvantages with respect to future clinical translation. This field is alive and well and promises meaningful contributions to the development of novel cancer therapies.
\end{abstract}

Keywords: magnetic nanomaterials; hyperthermia; magnetofection; drug delivery

\section{Introduction}

Using magnetic nanomaterials for drug delivery strategies has become a promising and effective method in animal models for cancer and other diseases [1,2], although no clinical method has obtained FDA approval to date [3]. The endeavor to utilize magnetic nanoparticles for the purpose of drug delivery in humans for curing various types of diseases started in 1996 [4]. Since then, numerous research groups have been involved in developing multiple types of approaches and tailored synthetic techniques for diverse types of magnetic nanomaterials to meet the drug delivery requirements. Some designs and techniques were successful, others were not [3]. In this review, we will discuss the most important designs of magnetic nanomaterials with regard to gene and drug delivery.

Magnetic nanoparticles have specific characteristics, such as small particle size, large specific surface area, and superparamagnetism [5]. Iron oxide nanoparticles are among the most frequently used nanomaterials [5]. They include magnetite $\left(\mathrm{Fe}_{3} \mathrm{O}_{4}\right)$ and maghemite $\left(\gamma-\mathrm{Fe}_{2} \mathrm{O}_{3}\right)$ nanoparticles [6]. Magnetic nanoparticles play a big role in cancer detection [7-9], drug delivery [2,3], as well as hyperthermia treatment [10-12]. During the last decade, bi-magnetic core/shell nanoparticles featuring an iron core and an iron oxide $\left(\mathrm{Fe}_{3} \mathrm{O}_{4}\right)$ shell have become widely used [13-19], due to their superior magnetic properties $[20,21]$.

As discussed above, magnetic nanoparticles have small diameters $(<100 \mathrm{~nm})$ so they can effectively extravasate [22] and target diseased areas [6], such as infected tissue (lesions) or tumor tissue. The mechanism of extravasation has been established in mouse models [22]. However, enhanced permeation and retention (EPR) is significantly less efficient in humans than in rodents [22-24]. Furthermore, there is significant variability of EPR among individual patients and various tumor types. The strength of EPR is also dependent on the lengths of treatment with nanoformulations against cancer [23,24]. Therefore, magnetic forces can be, principally, used to aid targeted drug delivery [3]. Due to their nanoscopic size, magnetic nanoparticles have very high surface areas $\left(>100 \mathrm{~m}^{2} / \mathrm{g}\right)$ and are, therefore, suitable to transport significant adsorbed or tethered payloads ( $>10 \%$ by weight). The general disadvantage of the high surface areas of magnetic nanoparticles is corona formation $[25,26]$, which is prevalent in living systems.

Magnetic nanoparticles play a major role in tumor imaging [6]. Magnetic resonance imaging (MRI) [27] uses superparamagnetic iron oxide nanoparticles as contrast agents [6]. Compared to 
gadolinium(III)-based contrast agents, iron oxide-based imaging tools have lower nephro- and cytotoxicities, which is advantageous [28]. Until recently, iron oxide-based imaging agents were limited to T2-based imaging (spin-spin relaxation [29]), whereas gadolinium(III)-based imaging modalities are capable of T1-based imaging (spin-gitter relaxation [29]), which is generally perceived as advantageous, because it provides positive imaging contrast. However, this has changed since the arrival of ultrasmall $\mathrm{Fe}_{2} \mathrm{O}_{3}$ clusters, which permit T1-based imaging [30,31].

Magnetic nanoparticles as drug carriers are also becoming very important for medical applications when the drug molecules have to target a specific location in vivo. In most published applications, magnetic nanoparticles are used as drug carriers in conjunction with tethered antibodies and chemotherapeutic drugs [6]. For example, antibody-conjugated fluorescent magnetic nanoparticles were used for targeted imaging and simultaneous therapy of gastric cancer [32], and reducible polyamidoamine-magnetic iron oxide self-assembled nanoparticles were used for doxorubicin delivery for cancer therapy [33].

There are major advantages of magnetic nanoparticles in drug delivery systems, such as MRI visualization and image-guided drug delivery, nanoparticle focusing by magnetic fields at the targeted site, and A/C-magnetic or radiofrequency-based hyperthermia to release the drugs from the magnetic carrier nanoparticle [34]. There are numerous factors that need to be considered when designing a magnetic nanoparticle-based targeting system, such as its size, magnetic properties, surface size, specific binding ability of drugs or genetic material, and targeting moieties (e.g., antibodies, peptide sequences of aptamers). Important technical factors comprise the magnetic field strength and dimension. Important physiological parameters have been identified as the targeted location, vascularization, rate of the blood flow, total body weight, and means of nanoparticle administration (oral, IV, IP, etc.) [35].

\section{Magnetic Nanoparticles}

During the last two decades, various strategies for synthesizing magnetic nanoparticles for drug delivery have been explored [36]. Magnetic nanoparticles consist of a core of magnetic iron oxide (magnetite $\left[\mathrm{Fe}_{3} \mathrm{O}_{4}\right]$ or maghemite $\left[\mathrm{Fe}_{2} \mathrm{O}_{3}\right]$ ), and a shell comprised of diamagnetic material, for instance, silica, dextran or polyvinyl alcohol (PVA) [6,37-39]. Noble metal shells (especially Au) were used to enable the attachment of functional groups and ligands via thiols [40,41]. However, many of these core/shell systems prove to be chemically unstable, leading to gold-iron oxide alloys [42].

Magnetic nanoparticles can be synthesized by using ionic and non-ionic techniques [43]. There are numerous methods known to synthesize magnetic nanoparticles, such as mechanical milling [44], co-precipitation [45], nanoreactor/microemulsion techniques [45,46], sonochemical processing [45,46], sol-gel methods [47], flow injection [43], electrochemical production [48], supercritical fluid techniques [49,50], thermal decomposition [13-16,22,51-55], hydrothermal routes [45], microwave techniques [56], spray pyrolysis [45], laser pyrolysis [45], flame spray pyrolysis [45], gas phase synthesis [45], arc discharge [57], oxidation [58,59], and microbial methods etc. [43,45,60]. Figure 1 shows a typical plot of resulting nanoparticle size distribution $\mathrm{p}(\mathrm{n})$ as a function of nucleation rate $J(t)$ and reaction time $(t)$ minus time of maximal nucleation $\left(t_{m}\right)$, divided by the half-life time of the nucleation burst [61]. Figures 2 and 3 give examples of the diversity of obtainable nanostructures. 


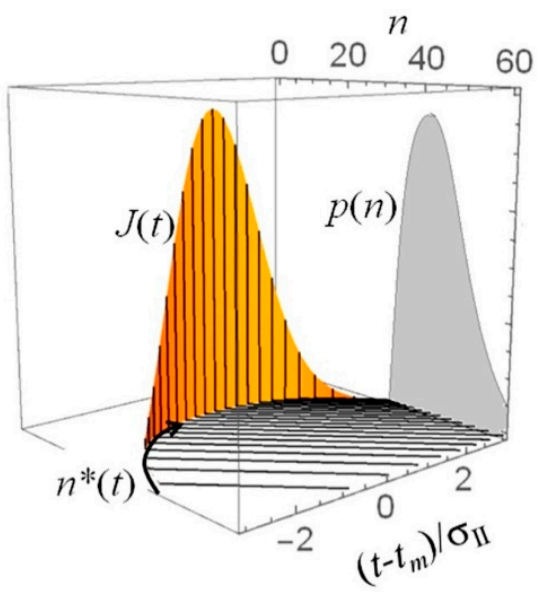

Figure 1. "As time increases toward $t_{m}$, the critical nucleus size decreases (black curved arrow), the nucleation rate increases (yellow manifold over nucleus size curve), and the earliest nuclei to form grow in the $(n, t)$ plane. The nucleation rate reaches a maximum at time $t_{m}$ and then begins to fall. The cumulative number of nuclei generated and carried along each characteristic gives the particle size distribution PSD p(n). For times after the pulse, the PSD simply travels along the characteristics with no change in shape." $n^{*}$ : critical nucleus size, $n$ : nucleus size, $2 \sigma_{I I}$ : approximate duration of the nucleation burst [61]. With permission from Chu, D. B. K.; Owen, J. S.; Peters, B., Nucleation and Growth Kinetics from LaMer Burst Data. J. Phys. Chem. A 2017, 121 (40), 7511-7517, copyright American Chemical Society 2017.

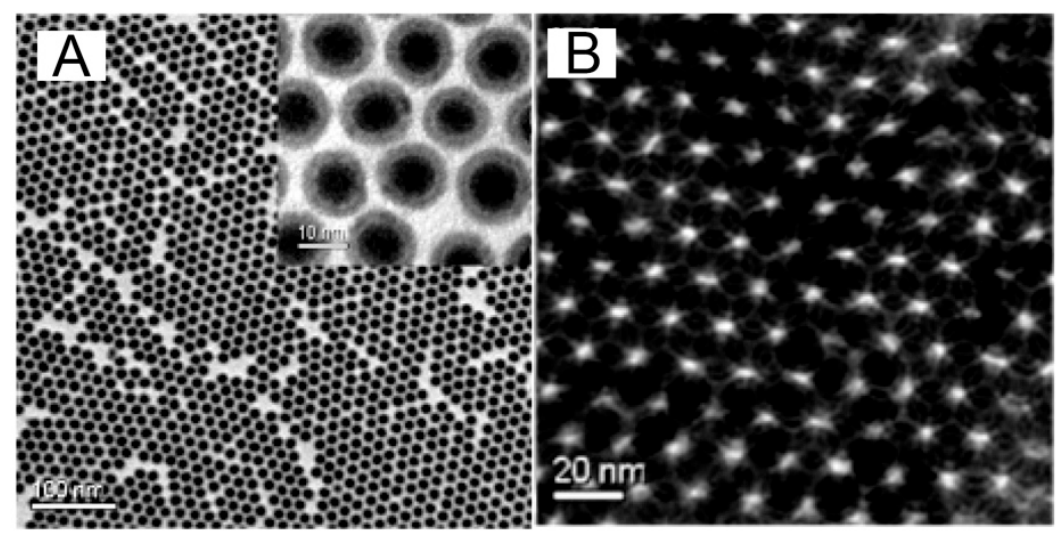

Figure 2. TEM images of (A) the as-synthesized $8 \mathrm{~nm} / 2.5 \mathrm{~nm} \mathrm{Fe} / \mathrm{Fe}_{3} \mathrm{O}_{4} \mathrm{NPs}$ (inset: HRTEM) and (B) the $5 \mathrm{~nm} / 5 \mathrm{~nm} \mathrm{Fe} / \mathrm{Fe}_{3} \mathrm{O}_{4}$ NPs prepared by controlled oxidation of Fe NPs [62]. With permission from Peng, S.; Wang, C.; Xie, J.; Sun, S., Synthesis and stabilization of monodisperse Fe nanoparticles. JACS 2006, 128 (33), 10676-10677, copyright American Chemical Society, 2006. 

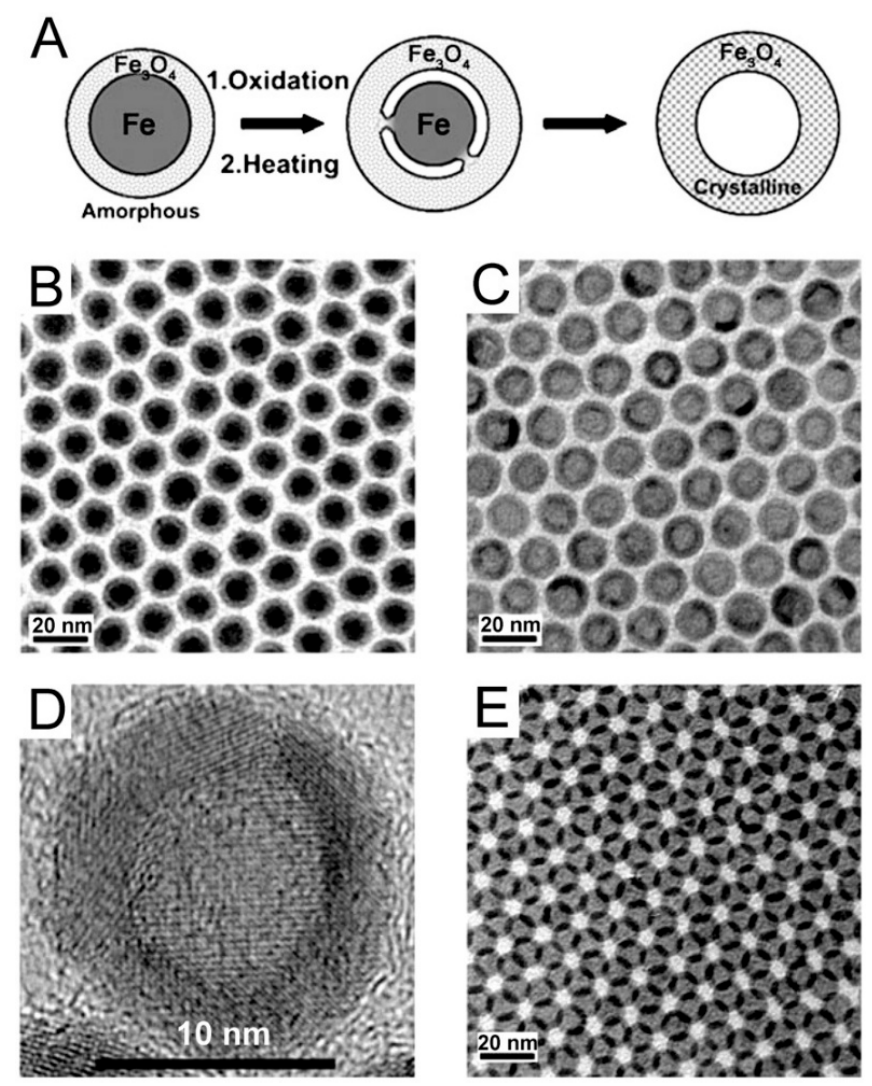

Figure 3. (A) "Synthesis of core-shell-void $\mathrm{Fe}-\mathrm{Fe}_{3} \mathrm{O}_{4}$ and hollow $\mathrm{Fe}_{3} \mathrm{O}_{4} \mathrm{NPs}$ from $\mathrm{Fe}-\mathrm{Fe}_{3} \mathrm{O}_{4} \mathrm{NP}$ seeds."; (B) TEM images: a 13-nm Fe- $\mathrm{Fe}_{3} \mathrm{O}_{4}$ nanoparticle seeds, (C) 16-nm hollow $\mathrm{Fe}_{3} \mathrm{O}_{4}$ nanoparticles, (D) a single hollow $\mathrm{Fe}_{3} \mathrm{O}_{4}$ nanoparticle, and (E) a superlattice array of the hollow $\mathrm{Fe}_{3} \mathrm{O}_{4}$ nanoparticles." [63] With permission from Peng, S.; Sun, S., Synthesis and characterization of monodisperse hollow Fe3O4 nanoparticles. Angewandte Chemie International Edition 2007, 46 (22), 4155-4158, copyright Wiley \& Sons, 2007.

These synthesized magnetic nanoparticles can be functionalized by attaching carboxyl groups, amines, biotin, streptavidin, antibodies, etc. $[64,65]$. By attaching functional groups to the magnetic nanoparticles one can change their physicochemical properties, such as solubility, reactivity, and stability (Figure 4) [64,65].
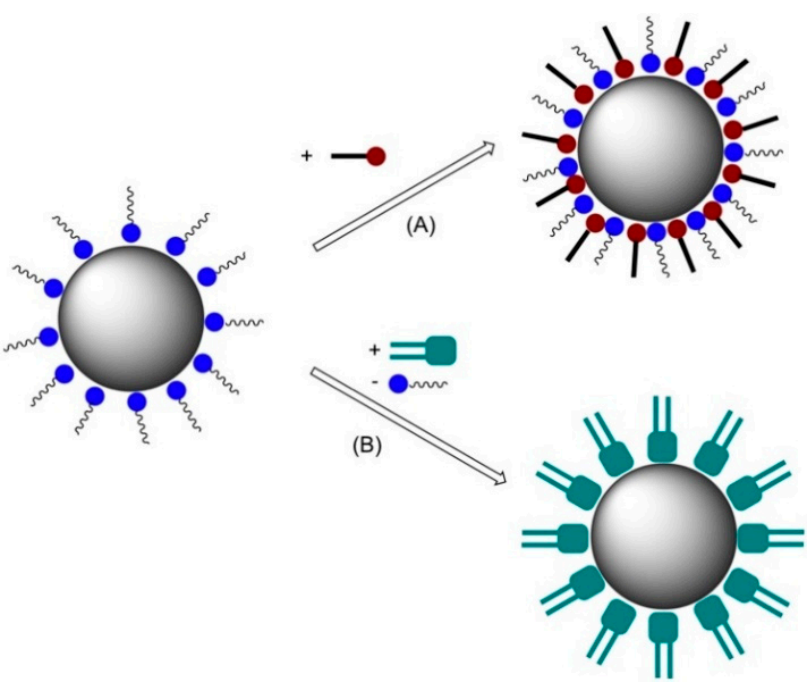

Figure 4. Nanoparticle surface functionalization via (A) surfactant addition and (B) surfactant exchange [64]. 


\section{Synthesis of Magnetic Nanoparticles}

There are some main features that we need to consider when synthesizing magnetic nanoparticles. The size of the nanoparticles, the magnetic properties, and the ability to carry biomolecules are a few of those features. Willard and co-workers have reported that the nanoparticles can flow with the bloodstream in blood vessels and penetrate through cell walls in order to avoid narrow blood vessels [66]. The ferromagnetic/superparamagnetic property of magnetic nanoparticles can lead them to the targeted organs/locations in the human body under the control of an external magnetic field [67]. Once the nanoparticles have reached the targeted area, they can release active biomolecules/drugs/genes, depending on the application. In order to meet the requirements, magnetic nanoparticles consist of the magnetic core, the protective coating, and the functional groups on the surface (Figure 5) [68].

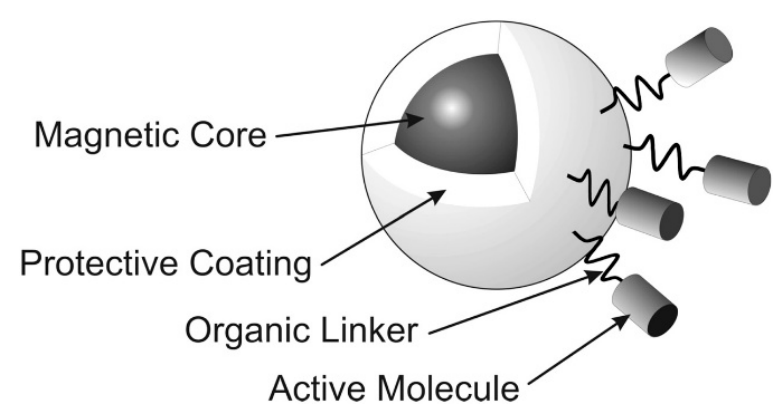

Figure 5. Consensus design of a functional magnetic nanoparticle for drug delivery [68]. With permission from McBain, S. C.; Yiu, H. H.; Dobson, J., Magnetic nanoparticles for gene and drug delivery. International journal of nanomedicine 2008, 3 (2), 169. Copyright Dove Medical Press, 2008.

There are various types of magnetic nanoparticle synthesis methods. Each method has their own advantages and disadvantages. Therefore, depending on the availability of facilities, instrumentation, and regulations, the correct synthetic path for the synthesis of specific magnetic nanoparticles has to be optimized following diverse synthetic routes [68]. The following discusses a few synthetic routes to synthesize magnetic nanoparticles.

\section{Wet Precipitation and Co-Precipitation}

This is one of the simplest and the oldest synthesis methods used for the synthesis of magnetic nanoparticles. In this method, the $\mathrm{pH}$ of an iron salt solution is carefully monitored and controlled while permitting an iron oxide fine suspension to form. Usually, the particle size of this suspension is around $5 \mathrm{~nm}$ [68]. There are no particular facilities or instrumentation required to follow this synthetic approach.

$\mathrm{Fe}_{3} \mathrm{O}_{4}$-nanoparticles can be prepared by the coprecipitation of $\mathrm{Fe}^{3+}$ and $\mathrm{Fe}^{2+}$ aqueous salts solution by adding a base as a precipitating agent. The actual $\mathrm{pH}$ at which $\mathrm{Fe}_{3} \mathrm{O}_{4}$ is formed is strongly dependent on the ionic strength. The point-of-zero-charge (PZT) of $\mathrm{Fe}_{3} \mathrm{O}_{4}$-nanoparticles is around $\mathrm{pH}=8$. Therefore, this $\mathrm{pH}$ should be avoided during synthesis, because otherwise coagulation will occur [69].

The precipitation of magnetite can be performed at the surface of montmorillonite (MMT), which assists $\mathrm{Fe}_{3} \mathrm{O}_{4}$ nucleation during the precipitation process [69].

$$
\mathrm{Fe}^{2+}+2 \mathrm{Fe}^{3+}+\mathrm{MMT}+8 \mathrm{OH}^{-} \rightarrow \mathrm{Fe}_{3} \mathrm{O}_{4} @ M M T+4 \mathrm{H}_{2} \mathrm{O}
$$

Accordingly, $\mathrm{Fe}_{3} \mathrm{O}_{4}$-nanoparticles can be found at the surface of MMT.

Wet precipitation methods are usually chosen for the synthesis of broad particle size distributions and irregular morphologies [68]. As can be anticipated, there are a few drawbacks associated with wet precipitation methods. Controlling the $\mathrm{pH}$ and ionic strength is critical for this procedure as it controls the particle size and morphology. Therefore, upscaling is a difficult challenge. 


\section{Utilizing the Reverse Micelle Mechanism for Magnetic Nanoparticle Synthesis}

The reverse micelle mechanism involves the formation of micelles by surfactants, which then provide the templates for nanoparticle synthesis (Scheme 1) [70,71]. Surfactants either consist of a hydrophilic head and a hydrophobic tail, or they are non-ionic [70,71]. Once the surfactant molecules reach a certain concentration in water, commonly called a critical micelle concentration ( $\mathrm{cmc}$ ), they form micelles [70,71].

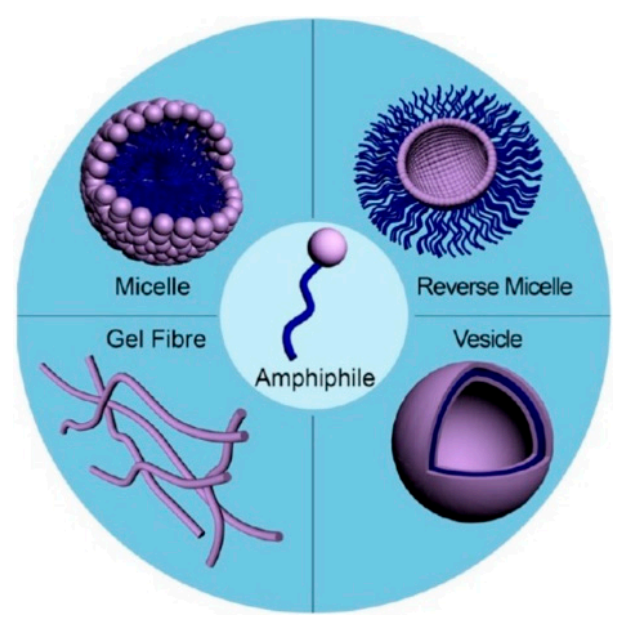

Scheme 1. Pictorial representation of different expressions of supramolecular self-assemblies (micelles, reverse micelles, vesicles, and gel fibers. Originating from Tailor-Made Amphiphiles) [70]. With permission from Sarkar, S.; Choudhury, P.; Dinda, S.; Das, P. K., Tailor-Made Self-Assemblies from Functionalized Amphiphiles: Diversity and Applications. Langmuir 2018, 34 (36), 10449-10468, copyright American Chemical Society 2018.

While normal micelles form in an aqueous medium, reverse micelles form in hydrophobic media [68,70]. The center of a normal micelle features hydrophobic tails, but the reverse micelles contain hydrophilic heads around water-droplets in their center. Nanoparticles synthesized by reverse micelle mechanism are very homogeneous in size, because the size of the inverse micelles used as nanoreactors can be easily defined (Figure 6) [70].
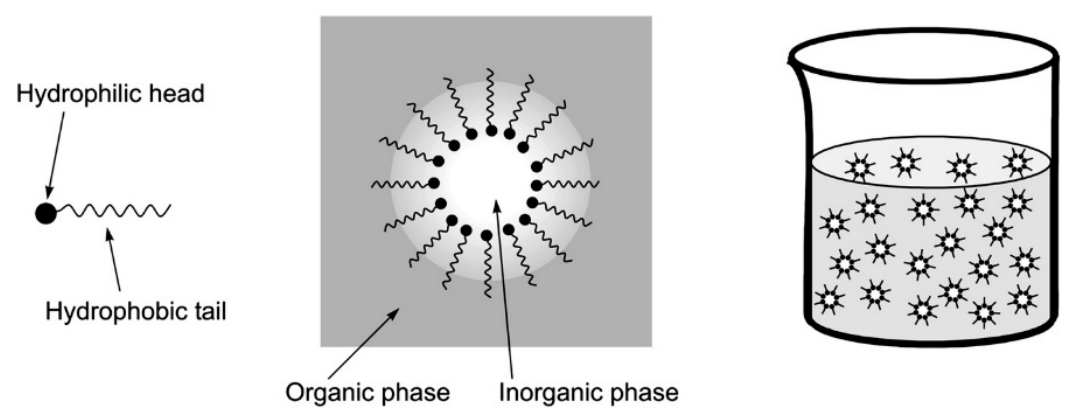

Figure 6. Use of the reverse micelle mechanism in synthesizing magnetic nanoparticles [68]. With permission from McBain, S. C.; Yiu, H. H.; Dobson, J., Magnetic nanoparticles for gene and drug delivery. International journal of nanomedicine 2008, 3 (2), 169. Copyright Dove Medical Press, 2008.

\section{Thermal Decomposition and Reduction}

In this procedure, metal oxy-salts are heated to a specific temperature, so they can decompose and form metal oxides. By heating these metal oxides under a reducing gas, such as hydrogen or carbon monoxide, metal oxide nanoparticles can be reduced to metal or metal oxides. The main obstacle of this procedure is the control of nanoparticle size and polydispersity. One of the major advantages is the opportunity to synthesize composite materials [72-75]. 


\section{Iron/Iron Oxide Core/Shell Nanoparticles}

Bossmann and co-workers have developed fluorescence-based nanobiosensors for the detection of solid tumors in liquid biopsies and protease detection in blood [18,22,76-78]. These nanobiosensors feature $\mathrm{Fe} / \mathrm{Fe}_{3} \mathrm{O}_{4}$ core/shell nanoparticles, which were synthesized by using thermal decomposition of $\mathrm{Fe}(\mathrm{CO})_{5}$ in the presence of oleylamine and hexadecylammonium chloride (HADxHCl) using 1-octadecene (ODE) as solvent [79]. The nanoparticles have a well-defined core/shell structure. These nanoparticles are characterized by a $\mathrm{Fe}(0)$ core diameter of $13 \pm 0.5 \mathrm{~nm}$, and the $\mathrm{Fe}_{3} \mathrm{O}_{4}$ shell thickness of $2.0 \pm 0.5 \mathrm{~nm}$ (Figure 7). They are coated with dopamine, which enhances the water solubility of the nanoparticles. To these dopamine-coated core/shell nanoparticles a FRET (Förster resonance energy transfer) pair is attached. While the FRET donor is attached by means of a protease or arginase-modifiable peptide sequence, the FRET acceptor is tethered by a stable amide bond to the dopamine ligands. The result is enzymatic activation of nanoplatform fluorescence, which enables the detection of protease activity down to sub-femtomolar limits of detection.

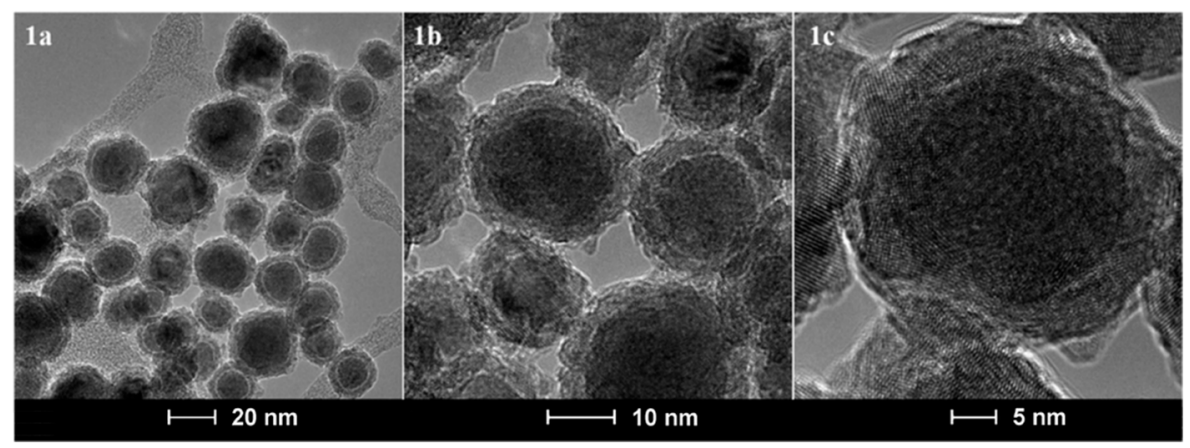

Figure 7. TEM (1a,1b) and HRTEM (1c) images of $\mathrm{Fe} / \mathrm{Fe}_{3} \mathrm{O}_{4}$-core/shell nanoparticles that are forming the inorganic core of the nanoplatforms for protease detection [79]. With permission from Wang, H.; Udukala, D. N.; Samarakoon, T. N.; Basel, M. T.; Kalita, M.; Abayaweera, G.; Manawadu, H.; Malalasekera, A.; Robinson, C.; Villanueva, D., Nanoplatforms for highly sensitive fluorescence detection of cancer-related proteases. Photochemical \& Photobiological Sciences 2014, 13 (2), 231-240.

Copyright Royal Society of Chemistry, 2014.

\section{Chemical Vapor Condensation Method}

The chemical vapor condensation method involves heating volatile metal compounds in an inert gas. Then these compounds can be decomposed and create metal nanoparticles. Choi and co-workers have used the chemical vapor condensation method and reported that the metallic iron nanoparticles can be prepared by using iron pentacarbonyl, $\mathrm{Fe}(\mathrm{CO})_{5}$, as a precursor. The particle size was in the range of 5-13 nm [80]. Needing specialized facilities is the major drawback associated with this method.

\section{Drug Delivery}

Drug delivery using magnetic nanoparticles has become a very popular topic due to the enhancement of performances in therapeutic drugs and their delivery to the targeted locations without side effects. Commonly, antibodies, chemotherapeutic drugs, and other disease-associated drugs are bound to the magnetic nanoparticles, and are directed to the targeted diseased areas in the human body [23].

Researchers have been studying the use of magnetic nano- and micro-materials for targeted drug delivery since the late 1970s. It has been noted that Lubbe and co-workers in 1996 did a Phase 1 clinical trial of magnetically targeted drug delivery for the first time [4]. Since then, different research groups have been using different strategies to synthesize magnetic drug carriers for drug delivery.

Magnetic nanoparticles loaded with doxorubicin were produced by FeRx, Inc., (Wheat Ridge, CO, USA) $[1,81]$. TargetMAG-doxorubicin nanoparticles involving a multidomain magnetite core 
and a cross-linked starch matrix with terminal cations are currently commercialized by Chemicell $\mathrm{GmbH}$, Berlin, Germany [82]. Alnis Biosciences, Berkely, CA, produces a magnetic nanoparticle hydrogel, which comprises chemotherapeutic agents, Fe oxide colloids, and different types of targeting ligands [83].

There are several good reasons to use nano-biotechnology in drug delivery such as its capability of targeting more specific drugs, biocompatibility, safety, and less toxicity. There are major factors that need to be considered when designing carriers for drug delivery. The incorporation of the drug to the carrier, stability, biocompatibility, biodistribution, targeting, and drug release, are just a few of them. It is very important to know the biodegradability of the nanoparticles, and the effect of residual materials as well.

The main advantages of magnetic nanoparticles are high surface-area-to-volume ratios so it is easy to attach a large number of therapeutic molecules, and the magnetic properties of nanoparticles help to image the drug delivery through MRI [84].

As stated above, magnetic nanoparticles have been used as chemotherapeutic drug carriers. At the same time, MNPs have been used to carry drugs such as doxorubicin, methotrexate [85] by attaching or encapsulating. Yang and co-workers have discovered the synthesis and release characteristics of magnetic PECA nanoparticles as drug carriers for targeted delivery [86]. In this study, magnetic poly(ethyl-2-cyanoacrylate) (PECA) nanoparticles containing anti-cancer drugs (Cisplatin and Gemcitabine) were prepared by inter-facial polymerization. It was also found that the amount of Cisplatin in MNPs is higher compared to the Gemcitabine. The reason is due to the hydrophobicity of Cisplatin. It has a high solubility in the oil phase and is well encapsulated in MNPs [86].

Zhou and co-workers developed magnetic nanoparticles coated with poly((2-dimethylamino) ethyl methacrylate) (PDMAEMA) for drug delivery and release [87]. These $\mathrm{Fe}_{3} \mathrm{O}_{4} / \mathrm{PDMAEMA}$ nanoparticles contain a core/shell structure and capable of loading drugs into the polymer shell. By altering the $\mathrm{pH}$, the release rate of the drug can be effectively controlled [87]. They have synthesized nanoparticles with biodegradability, superparamagnetism, and fluorescence as well [88].

They used an external magnetic field to deliver the drug-loaded nanoparticles to the target organs. The release of the drug at the targeted location was slow and steady [88].

By modifying the drugs with antibodies, proteins, or ligands, it is possible to improve the drug delivery in vitro. Chitosan coated $\mathrm{Fe}_{2} \mathrm{O}_{3}$ magnetic nanoparticles were suggested by Kumar and co-workers [89]. These nanoparticles are safe to transport to the targeted organs and became one of the most useful tools in drug delivery [89]. Sun and co-workers prepared magnetic targeting chitosan nanoparticles and were used as a drug delivery system [90]. This nanoparticle based drug delivery system was targeting photodynamic therapy [90]. In photodynamic therapy, a tumor localizing photosensitizing agent would be administered and activated by light of a particular wavelength [91].

In the study carried out by the Jain and co-workers, they investigated the drug delivery and magnetic resonance imaging (MRI) properties of novel oleic acid-coated iron-oxide and pluronic-stabilized magnetic nanoparticles [92]. It has been recorded that the drug loading efficiency for doxorubicin and paclitaxel in magnetic nanoparticles was 74-95\% [92]. The combination of drugs incorporated in magnetic nanoparticles showed a high antiproliferative activity in MCF-7 breast cancer cells [92].

Kohler and co-workers reported the development of a methotrexate-immobilized iron oxide nanoparticle drug carrier which is biostable, and that may be used for real-time monitoring of drug delivery through magnetic resonance imaging [93]. Methotrexate was attached to the nanoparticle via a poly(ethylene glycol) self-assembled monolayer. Cytotoxicity was studied by using 9L glioma cells. Experiments showed that the uptake of methotrexate attached nanoparticles by glioma cells higher compared to the control nanoparticles [93]. 


\section{Superparamagnetism vs. Ferromagnetism in Magnetic Nanoparticles}

The magnetic behavior and size dependence of magnetic nanoparticles is controlled by their domain structures [94,95]. The critical size of single domains is governed by the shape of the particle, the strength of the crystal anisotropy, magnetic saturation, and the domain wall energy. As shown in Figure 8, superparamagnetic, single-domain and multi-domain nanoparticles can be discerned with increasing radius. The domain walls in magnetic particles have a major impact on the magnetization of the particles. Magnetic moments will scale with the volume of the nanoparticle. However, because of the presence of domain walls, this scaling is abruptly halted when multiple magnetic domains are formed in a single (nano) particle. The critical radius $\left(\mathrm{r}_{\mathrm{c}}\right)$ represents the size where it is energetically favored for the magnetic nanoparticle to exist without a domain wall [96].

$$
r_{c} \sim f\left(\frac{\sigma}{M_{s}^{2}}\right)
$$

where $\sigma$ represents the magnetic moment per unit mass and $M_{s}^{2}$ is the saturation magnetization. In Figure 8, it is shown that the coercivity (=resistance of a magnetic material to changes in magnetization) is a function of nanoparticle diameter. In the multi-domain region, coercivity decreases with increasing particle diameter (due to subdivision into domains), while in the single-domain region it increases with the radius of the particle. The calculated critical radii for some common magnetic material are $\mathrm{Fe}_{3} \mathrm{O}_{4}$ $(4 \mathrm{~nm}), \mathrm{Co}(8 \mathrm{~nm}), \mathrm{Fe}(1 \mathrm{~nm})$ and $\mathrm{Ni}(35 \mathrm{~nm})$ [94]. The single-domain region contains subregions: "the superparamagnetic region, where the coercivity is 0 due to the randomizing effects of the thermal energy, and the ferromagnetic region, where the coercivity increases dramatically with the particle diameter. In the absence of a magnetic field, the net magnetic moment is 0 for superparamagnetic nanoparticles, while in an applied magnetic field there will be a net alignment of the magnetic moments." [94].

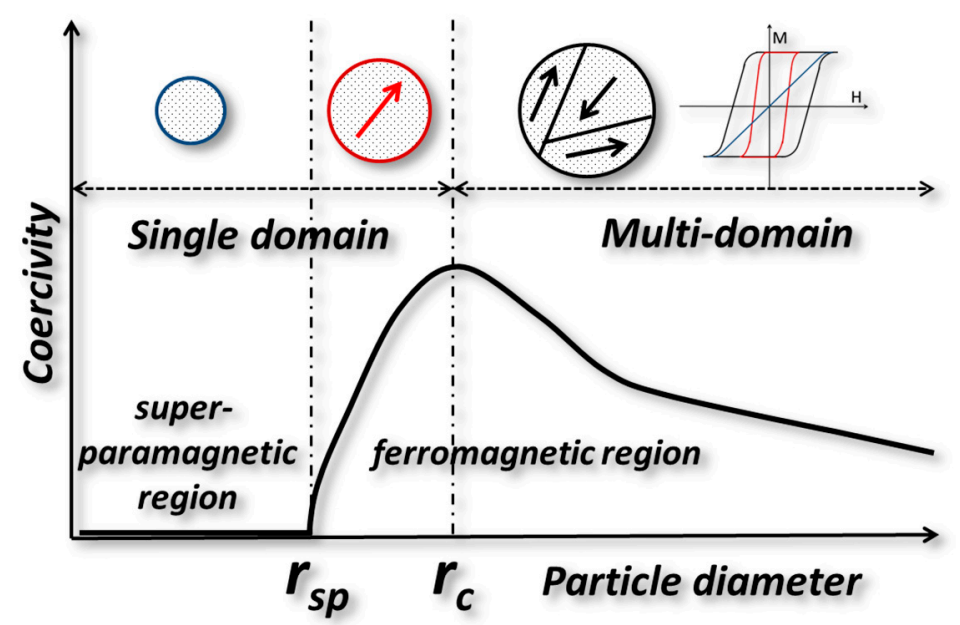

Figure 8. The change in coercivity of magnetic particles as a function of size. $r_{\mathrm{c}}$ : critical parameter, $\mathrm{r}_{\mathrm{sp}}$ : threshold radius for superparamagnetism. With permission from Podaru, G.; Chikan, V., Magnetism in Nanomaterials: Heat and Force from Colloidal Magnetic Particles. In Magnetic Nanomaterials: Applications in Catalysis and Life Sciences, Bossmann, S. H.; Wang, H., Eds. Royal Society of Chemistry: London/UK, 2017; Vol. 26, 1-21. Copyright Royal Society of Chemistry, 2017.

\section{Magnetic Nanoparticles in Preclinical Studies}

There are two main factors that need to be considered when MNPs are used in clinical settings: biological challenges and chemical challenges [97]. Biodistribution of MNPs, biological barriers and pharmacokinetics are a few biological challenges [97]. Chemical challenges include optimizing physicochemical properties, intrinsic toxicities, and drug loading and release. Further, MNPs should be biologically inert and should be composed of biodegradable and 
non-toxic materials [97]. Most of the research groups have used $\mathrm{Fe}_{3} \mathrm{O}_{4}$ or $\gamma$ - $\mathrm{Fe}_{2} \mathrm{O}_{3}$ coated with different materials for clinical purposes [35]. Iron-oxide nanoparticles doped with Gd(III) has been used to treat tumors via magnetic fluid hyperthermia (MFH). Jiang and co-workers have found that the mouse models treated with $\mathrm{Gd}_{0.02} \mathrm{Fe}_{2.98} \mathrm{O}_{4}$ show slower tumor growth after the first treatment cycle [98]. Xie and co-workers synthesized Mn-Zn ferrite MNCs coated with PEG-phospholipids (1,2-distearoyl-sn-glycero-3-phosphoethanolamine- $N$-methoxy(polyethylene glycol) copolymers, DSPE-PEG2000) to treat tumors, and they were able to use them to induce the apoptosis of tumor cells and inhibit the angiogenesis of tumor vessels. This enables the suppression of tumor growth within a certain period of time [99].

Lee and co-workers have developed versatile nanocomposite nanoparticles by decorating the surface of mesoporous silica nanoparticles with magnetite nanocrystals. These nanoparticles were able to be used in magnetic resonance (MR) imaging (Figure 9). The authors found that doxorubicin (DOX), which is an anticancer drug, can be loaded in the pores of the nanoparticles and induce cell death. In-vivo passive targeting and nanoparticle accumulation at tumor sites were confirmed using T2 magnetic resonance imaging and fluorescence imaging [100].

a)

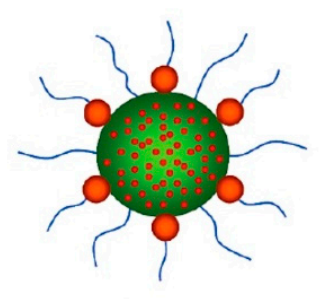

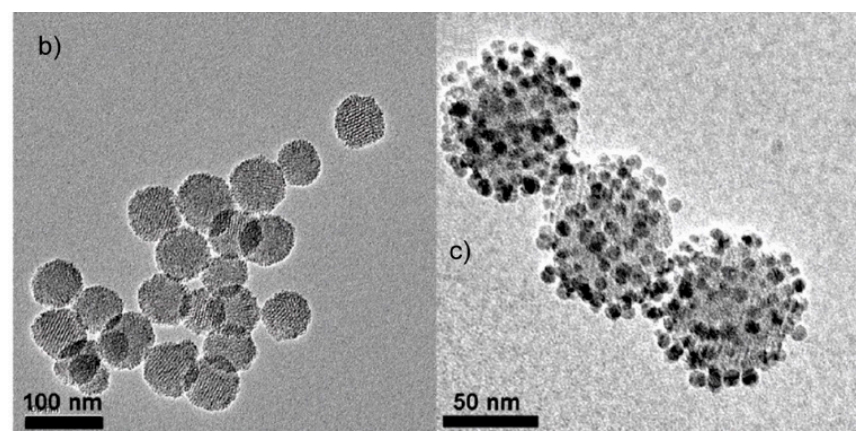

Figure 9. "Uniform mesoporous dye-doped silica nanoparticles immobilized with multiple magnetite nanocrystals on the surface (designated as $\mathrm{Fe}_{3} \mathrm{O}_{4}-\mathrm{MSN}$ )" [100]: (a) cartoon of the nanoplatform, (b) TEM images of the carrier MSN, (c) TEM image of the $\mathrm{Fe}_{3} \mathrm{O}_{4}-\mathrm{MSN}$, with permission from Lee, J. E.; Lee, N.; Kim, H.; Kim, J.; Choi, S. H.; Kim, J. H.; Kim, T.; Song, I. C.; Park, S. P.; Moon, W. K.; Hyeon, T., Uniform mesoporous dye-doped silica nanoparticles decorated with multiple magnetite nanocrystals for simultaneous enhanced magnetic resonance imaging, fluorescence imaging, and drug delivery. JACS 2009, 132 (2), 552-557. Copyright American Chemical Society 2009.

In order to monitor if DOX was successfully delivered to the tumor sites, tumor tissue of mice treated with DOX was analyzed and compared to a control group. Apoptosis was detected in treated tissue by means of a TUNEL assay (Terminal deoxynucleotidyl transferase-mediated nick end labeling). This confirmed the delivery of the anticancer drug to the tumor sites, and that its activity was retained during the process (Figure 10) [100]. 

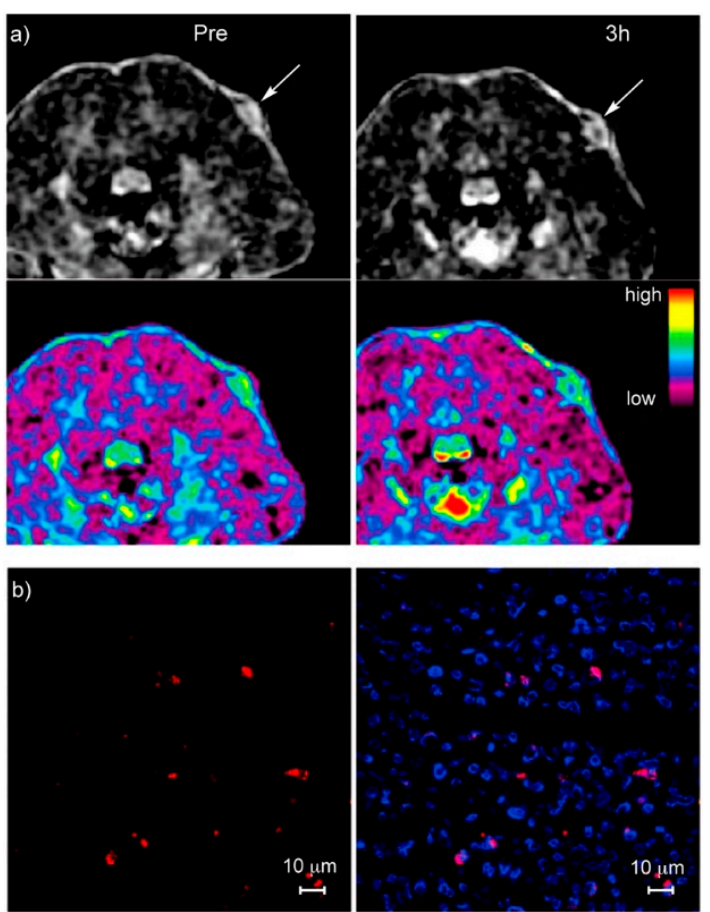

Figure 10. "In-vivo accumulation of $\mathrm{Fe}_{3} \mathrm{O}_{4}-\mathrm{MSN}$ at tumor site. (a) In-vivo T2 weighted MR images (upper) and color mapped (lower) images of tumor site before and $3 \mathrm{~h}$ after intravenous injection of $\mathrm{Fe}_{3} \mathrm{O}_{4}$-MSN (arrows indicate tumor site). (b) Confocal laser scanning microscopic images of sectioned tumor tissue harvested $24 \mathrm{~h}$ after injection. Left: Red fluorescence showing $\mathrm{Fe}_{3} \mathrm{O}_{4}$-MSN internalized cells. Right: Merged image with DAPI stained nuclei (blue) (scale bar) $10 \mu \mathrm{m}$ )." [100], with permission from Lee, J. E.; Lee, N.; Kim, H.; Kim, J.; Choi, S. H.; Kim, J. H.; Kim, T.; Song, I. C.; Park, S. P.; Moon, W. K.; Hyeon, T., Uniform mesoporous dye-doped silica nanoparticles decorated with multiple magnetite nanocrystals for simultaneous enhanced magnetic resonance imaging, fluorescence imaging, and drug delivery. JACS 2009, 132 (2), 552-557. Copyright American Chemical Society 2009.

Yang and co-workers have developed a multifunctional system in order to deliver drugs intracellularly, while they monitor this process with simultaneous fluorescent imaging. This system is composed of histidine-tagged, cyan fluorescent protein (CFP)-capped, magnetic mesoporous silica nanoparticles (MMSNs). As often found with mesoporous silica nanoparticles, this multifunctional nanostructure is excellently biocompatible. Histidine replacement at the surface of the MMSNs activates the nano-assembly and facilitates the release of the drug molecules. These bi-functional nanoplatforms are very useful in biomedical applications as they contain both drug delivery and cell-imaging abilities [101].

$\mathrm{Hwu}$ and co-workers have developed three paclitaxel-conjugated nanoparticles using $\mathrm{Fe}_{3} \mathrm{O}_{4}$ shells (Scheme 2) and gold cores (not shown). $\mathrm{Fe}_{3} \mathrm{O}_{4}$ nanoparticles were conjugated with paclitaxel that was attached by means of a poly(ethylene glycol) (PEG) spacer through a phosphodiester moiety at the (C-2')-OH position. In the presence of phosphodiesterase, these nanoparticles release paclitaxel. These nanoparticles have magnetic tracking capability. Different methods were discussed to synthesize $\mathrm{Au}-\mathrm{NPs}$ in order to produce both hydrophilic and hydrophobic paclitaxel conjugates [102]. 


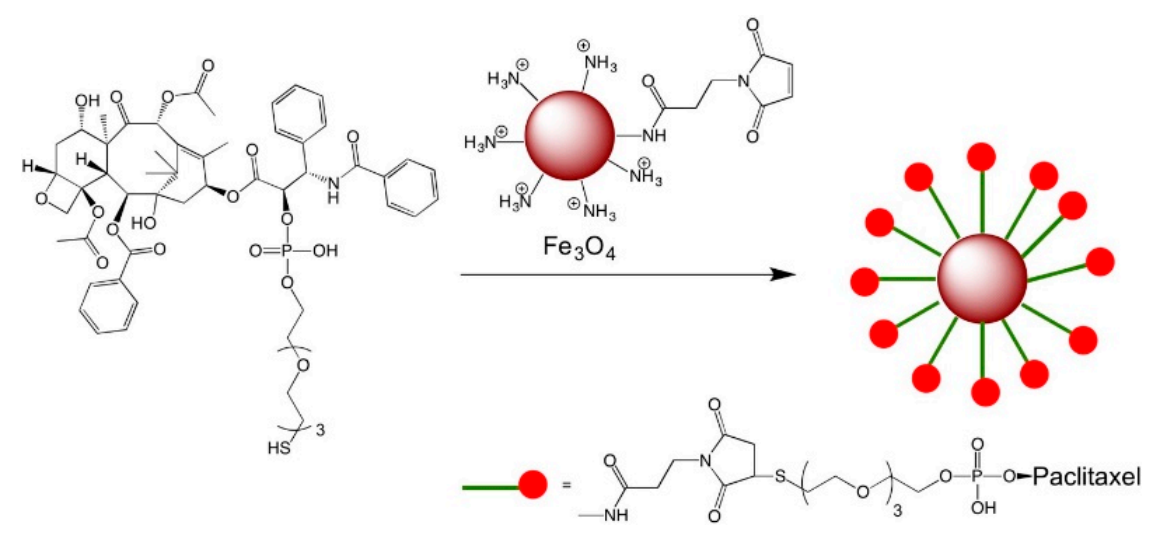

Scheme 2. Synthesis of $\mathrm{Fe}_{3} \mathrm{O}_{4}$ nanoparticles with tethered paclitaxel units. The linker can be cleaved by a phosphodiesterase, facilitating the release of paclitaxel. This scheme was inspired by reference [102]. Copyright American Chemical Society 2008.

Bai and co-workers found that the gold nanorods modified with carboxylated bovine serum albumin showed both anti-tumor and anti-angiogenesis effects under near-infrared laser irradiation. Magnetic resonance imaging (MRI) and near-infrared fluorescence (NIRF) imaging showed that the Den-RGD (nanoprobe, Dendrimer-arginine-glycine-aspartic acid) visualized the tumors with high target-to-background ratio, and the ability to evaluate the therapeutic response by monitoring the tumor neovasculature [103]. Jaiswal and co-workers have synthesized dual stimuli $\mathrm{pH}$ and temperature-responsive magnetic nanohydrogels based on poly( $N$-isopropylacrylamide)-chitosan for thermo-chemotherapy [104]. They have incorporated $\mathrm{Fe}_{3} \mathrm{O}_{4}$ magnetic nanoparticles into hydrogels to achieve temperature optimized magnetic nanohydrogel (MNHG) for magnetic hyperthermia with lower critical solution temperature which is less than $42{ }^{\circ} \mathrm{C}$ [104].

\section{Conclusions}

During the past few years, the development of magnetic nanoparticles for drug delivery and imaging has accelerated. Various types of magnetic nanoparticles have been synthesized and coated with different types of coatings in order to enhance the biocompatibility, non-toxicity, safety, stability, bio-distribution, etc. Enormous attention to magnetic nanoparticles was given, as they can be used for early cancer detection and as a contrast agent for MRI imaging and, thus, provide new opportunities to diagnose and cure cancer and various types of other diseases.

Author Contributions: Conceptualization, M.K. and S.H.B.; Resources, K.J.; Writing-Original Draft Preparation, M.K., K.J., and S.H.B.; Writing-Review \& Editing, K.J. and S.H.B.; Visualization, S.H.B.; Supervision, S.H.B.; Project Administration, S.H.B.; Funding Acquisition, S.H.B.

Funding: The research was funded by the National Science Foundation (NSF), grant numbers 1804416.

Conflicts of Interest: The authors declare no conflict of interest.

\section{References}

1. Goodwin, S.; Peterson, C.; Hoh, C.; Bittner, C. Targeting and retention of magnetic targeted carriers (MTCs) enhancing intra-arterial chemotherapy. J. Magn. Magn. Mater. 1999, 194, 132-139. [CrossRef]

2. Mathiyazhakan, M.; Xu, C. Magnetic Nanoparticles for Drug Delivery; World Scientific Publishing Co. Pte. Ltd.: Hackensack, NJ, USA, 2016; pp. 65-84.

3. Chang, D.; Lim, M.; Goos, J.A.C.M.; Qiao, R.; Ng, Y.Y.; Mansfeld, F.M.; Jackson, M.; Davis, T.P.; Kavallaris, M. Biologically Targeted Magnetic Hyperthermia: Potential and Limitations. Front. Pharmacol. 2018, 9, 831. [CrossRef] [PubMed]

4. Lübbe, A.S.; Bergemann, C.; Riess, H.; Schriever, F.; Reichardt, P.; Possinger, K.; Matthias, M.; Dörken, B.; Herrmann, F.; Gürtler, R. Clinical experiences with magnetic drug targeting: A phase I study with $4^{\prime}$-epidoxorubicin in 14 patients with advanced solid tumors. Cancer Res. 1996, 56, 4686-4693. [PubMed] 
5. Yarar, E.; Karakas, G.; Rende, D.; Ozisik, R.; Malta, S. Influence of Surface Coating of Magnetic Nanoparticles on Mechanical Properties of Polymer Nanocomposites; APS March Meeting Abstracts: Boston, MA, USA, 2016.

6. Wu, M.; Huang, S. Magnetic nanoparticles in cancer diagnosis, drug delivery and treatment. Mol. Clin. Oncol. 2017, 7, 738-746. [CrossRef] [PubMed]

7. Huang, S.; Chen, G.; Chaker, M.; Ozaki, T.; Tijssen, P.; Ma, D. Fluorescent-magnetic multifunctional nanoparticles for imaging and drug delivery. Rev. Nanosci. Nanotechnol. 2013, 2, 346-364. [CrossRef]

8. Maldiney, T.; Mignet, N. Nanoparticles for Imaging and Imaging Nanoparticles: State of the Art and Current Prospects; Wiley-VCH Verlag GmbH \& Co. KGaA: Weinheim, Germany, 2017; pp. 533-560.

9. Zeng, L.; Wu, D.; Zou, R.; Chen, T.; Zhang, J.; Wu, A. Paramagnetic and Superparamagnetic Inorganic Nanoparticles for T1-Weighted Magnetic Resonance Imaging. Curr. Med. Chem. 2018, 25, $2970-2986$. [CrossRef] [PubMed]

10. Kobayashi, T.; Kakimi, K.; Nakayama, E.; Jimbow, K. Antitumor immunity by magnetic nanoparticle-mediated hyperthermia. Nanomedicine 2014, 9, 1715-1726. [CrossRef] [PubMed]

11. Dutz, S.; Mueller, R.; Eberbeck, D.; Hilger, I.; Zeisberger, M. Magnetic nanoparticles adapted for specific biomedical applications. Biomed. Tech. 2015, 60, 405-416. [CrossRef]

12. Kafrouni, L.; Savadogo, O. Recent progress on magnetic nanoparticles for magnetic hyperthermia. Prog. Biomater. 2016, 5, 147-160. [CrossRef]

13. Balivada, S.; Rachakatla, R.S.; Wang, H.; Samarakoon, T.N.; Dani, R.K.; Pyle, M.; Kroh, F.O.; Walker, B.; Leaym, X.; Koper, O.B.; et al. A/C magnetic hyperthermia of melanoma mediated by iron(0)/iron oxide core/shell magnetic nanoparticles: A mouse study. BMC Cancer 2010, 10, 119. [CrossRef]

14. Wang, H.; Shrestha, T.B.; Basel, M.T.; Dani, R.K.; Seo, G.-M.; Balivada, S.; Pyle, M.M.; Prock, H.; Koper, O.B.; Thapa, P.S.; et al. Magnetic-Fe/ $\mathrm{Fe}_{3} \mathrm{O}_{4}$-nanoparticle-bound SN38 as carboxylesterase-cleavable prodrug for the delivery to tumors within monocytes/macrophages. Beilstein J. Nanotechnol. 2012, 3, 444-455. [CrossRef]

15. McWilliams, B.T.; Wang, H.; Binns, V.J.; Curto, S.; Bossmann, S.H.; Prakash, P. Experimental investigation of magnetic nanoparticle-enhanced microwave hyperthermia. J. Funct. Biomater. 2017, 8, 21. [CrossRef] [PubMed]

16. He, R.; Wang, H.; Su, Y.; Chen, C.; Xie, L.; Chen, L.; Yu, J.; Toledo, Y.; Abayaweera, G.S.; Zhu, G.; et al. Incorporating 131I into a PAMAM (G5.0) dendrimer-conjugate: Design of a theranostic nanosensor for medullary thyroid carcinoma. RSC Adv. 2017, 7, 16181-16188. [CrossRef]

17. Mehta, J.P.; Knappett, B.R.; Divitini, G.; Ringe, E.; Midgley, P.A.; Fairen-Jimenez, D.; Wheatley, A.E.H. Advances in the Synthesis and Long-Term Protection of Zero-Valent Iron Nanoparticles. Part. Part. Syst. Charact. 2018, 35, 1-8. [CrossRef]

18. Kalubowilage, M.; Covarrubias-Zambrano, O.; Malalasekera, A.P.; Wendel, S.O.; Wang, H.; Yapa, A.S.; Chlebanowski, L.; Toledo, Y.; Ortega, R.; Janik, K.E.; et al. Early detection of pancreatic cancers in liquid biopsies by ultrasensitive fluorescence nanobiosensors. Nanomedicine 2018, 14, 1823-1832. [CrossRef] [PubMed]

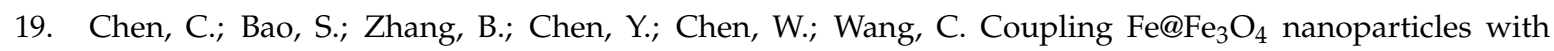
multiple-walled carbon nanotubes with width band electromagnetic absorption performance. Appl. Surf. Sci. 2019, 467-468, 836-843. [CrossRef]

20. Lopez-Ortega, A.; Estrader, M.; Salazar-Alvarez, G.; Roca, A.G.; Nogues, J. Applications of exchange coupled bi-magnetic hard/soft and soft/hard magnetic core/shell nanoparticles. Phys. Rep. 2015, 553, 1-32. [CrossRef]

21. Ong, Q.K.; Lin, X.-M.; Wei, A. Role of Frozen Spins in the Exchange Anisotropy of Core-Shell Fe@ $\mathrm{Fe}_{3} \mathrm{O}_{4}$ Nanoparticles. J. Phys. Chem. C 2011, 115, 2665-2672. [CrossRef]

22. Malalasekera, A.P.; Bossmann, S.H.; Zhu, G. Magnetic Nanoformulations for Enhanced Drug Delivery and Retention. In Magnetic Nanomaterials: Applications in Catalysis and Life Sciences; Bossmann, S.H., Wang, H., Eds.; RSC: London, UK, 2017.

23. Bertrand, N.; Wu, J.; Xu, X.; Kamaly, N.; Farokhzad, O.C. Cancer nanotechnology: The impact of passive and active targeting in the era of modern cancer biology. Adv. Drug Deliv. Rev. 2014, 66, 2-25. [CrossRef]

24. Shi, J.; Kantoff, P.W.; Wooster, R.; Farokhzad, O.C. Cancer nanomedicine: Progress, challenges and opportunities. Nat. Rev. Cancer 2017, 17, 20-37. [CrossRef]

25. Casals, E.; Puntes, V.F. Inorganic nanoparticle biomolecular corona: Formation, evolution and biological impact. Nanomedicine 2012, 7, 1917-1930. [CrossRef] [PubMed] 
26. Docter, D.; Westmeier, D.; Markiewicz, M.; Stolte, S.; Knauer, S.K.; Stauber, R.H. The nanoparticle biomolecule corona: Lessons learned - challenge accepted? Chem. Soc. Rev. 2015, 44, 6094-6121. [CrossRef] [PubMed]

27. Lu, A.-H.; Zhang, X.-Q.; Sun, Q.; Zhang, Y.; Song, Q.; Schüth, F.; Chen, C.; Cheng, F. Precise synthesis of discrete and dispersible carbon-protected magnetic nanoparticles for efficient magnetic resonance imaging and photothermal therapy. Nano Res. 2016, 9, 1460-1469. [CrossRef]

28. Shen, Z.; Song, J.; Zhou, Z.; Yung, B.C.; Aronova, M.A.; Li, Y.; Dai, Y.; Fan, W.; Liu, Y.; Li, Z.; et al. Dotted Core-Shell Nanoparticles for T1-Weighted MRI of Tumors. Adv. Mater. (Weinheim, Ger.) 2018, 30, 1803163. [CrossRef] [PubMed]

29. Shen, Z.; Wu, A.; Chen, X. Iron Oxide Nanoparticle Based Contrast Agents for Magnetic Resonance Imaging. Mol. Pharm. 2017, 14, 1352-1364. [CrossRef] [PubMed]

30. Mao, X.; Xu, J.; Cui, H. Functional nanoparticles for magnetic resonance imaging. Wiley Interdiscip. Rev. Nanomed. Nanobiotechnol. 2016, 8, 814-841. [CrossRef] [PubMed]

31. Bao, Y.; Sherwood, J.A.; Sun, Z. Magnetic iron oxide nanoparticles as T1 contrast agents for magnetic resonance imaging. J. Mater. Chem. C 2018, 6, 1280-1290. [CrossRef]

32. Wang, C.; Bao, C.; Liang, S.; Zhang, L.; Fu, H.; Wang, Y.; Wang, K.; Li, C.; Deng, M.; Liao, Q. HAI-178 antibody-conjugated fluorescent magnetic nanoparticles for targeted imaging and simultaneous therapy of gastric cancer. Nanoscale Res. Lett. 2014, 9, 274. [CrossRef]

33. Chen, J.; Shi, M.; Liu, P.; Ko, A.; Zhong, W.; Liao, W.; Xing, M.M. Reducible polyamidoamine-magnetic iron oxide self-assembled nanoparticles for doxorubicin delivery. Biomaterials 2014, 35, 1240-1248. [CrossRef]

34. Arruebo, M.; Fernández-Pacheco, R.; Ibarra, M.R.; Santamaría, J. Magnetic nanoparticles for drug delivery. Nano Today 2007, 2, 22-32. [CrossRef]

35. Neuberger, T.; Schöpf, B.; Hofmann, H.; Hofmann, M.; Von Rechenberg, B. Superparamagnetic nanoparticles for biomedical applications: Possibilities and limitations of a new drug delivery system. J. Magn. Magn. Mater. 2005, 293, 483-496. [CrossRef]

36. Ling, D.; Lee, N.; Hyeon, T. Chemical Synthesis and Assembly of Uniformly Sized Iron Oxide Nanoparticles for Medical Applications. Acc. Chem. Res. 2015, 48, 1276-1285. [CrossRef] [PubMed]

37. Santra, S.; Tapec, R.; Theodoropoulou, N.; Dobson, J.; Hebard, A.; Tan, W. Synthesis and characterization of silica-coated iron oxide nanoparticles in microemulsion: The effect of nonionic surfactants. Langmuir 2001, 17, 2900-2906. [CrossRef]

38. Pardoe, H.; Chua-Anusorn, W.; Pierre, T.G.S.; Dobson, J. Structural and magnetic properties of nanoscale iron oxide particles synthesized in the presence of dextran or polyvinyl alcohol. J. Magn. Magn. Mater. 2001, 225, 41-46. [CrossRef]

39. Jeun, M.; Bae, S.; Tomitaka, A.; Takemura, Y.; Park, K.H.; Paek, S.H.; Chung, K.-W. Effects of particle dipole interaction on the ac magnetically induced heating characteristics of ferrite nanoparticles for hyperthermia. Appl. Phys. Lett. 2009, 95, 082501. [CrossRef]

40. Kwizera, E.A.; Chaffin, E.; Wang, Y.; Huang, X. Synthesis and properties of magnetic-optical core-shell nanoparticles. RSC Adv. 2017, 7, 17137-17153. [CrossRef] [PubMed]

41. Sabale, S.; Kandesar, P.; Jadhav, V.; Komorek, R.; Motkuri, R.K.; Yu, X.-Y. Recent developments in the synthesis, properties, and biomedical applications of core/shell superparamagnetic iron oxide nanoparticles with gold. Biomater. Sci. 2017, 5, 2212-2225. [CrossRef] [PubMed]

42. Cho, S.-J.; Shahin, A.M.; Long, G.J.; Davies, J.E.; Liu, K.; Grandjean, F.; Kauzlarich, S.M. Magnetic and Moessbauer Spectral Study of Core/Shell Structured Fe/Au Nanoparticles. Chem. Mater. 2006, 18, 960-967. [CrossRef]

43. Baker, I. Magnetic nanoparticle synthesis. In Nanobiomaterials; Elsevier: Amsterdam, The Netherlands, 2018; pp. 197-229.

44. Hajalilou, A.; Kianvash, A.; Lavvafi, H.; Shameli, K. Nanostructured soft magnetic materials synthesized via mechanical alloying: A review. J. Mater. Sci. Mater. Electron. 2018, 29, 1690-1717. [CrossRef]

45. Latha, G.; Kumar, P.D.; Gopi, K.; Srikanth, P.; Kusumalatha, Y.; Babu, G.V. A review on magnetic micro/nanoparticles. World J. Pharm. Res. 2017, 6, 341-366. [CrossRef]

46. Jamil, S.; Janjua, M.R.S.A. Synthetic Study and Merits of Fe3O4 Nanoparticles as Emerging Material. J. Cluster Sci. 2017, 28, 2369-2400. [CrossRef] 
47. Geinguenaud, F.; De Montferrand, C.; Jouni, H.; Guenin, E.; Milosevic, I.; Benyettou, F.; Lalatonne, Y.; Motte, L. Magnetic nanoparticle surface functionalization for biomedical applications. In Nanoantenna; Pan Stanford Series on the High-tech of Biotechnology; Jenny Stanford Publishing: Singapore, 2013; Volume 1, pp. 103-149.

48. Magagnin, L.; Cojocaru, P. Electrochemical synthesis of dispersed metallic nanoparticles. Mod. Aspects Electrochem. 2012, 54, 345-368.

49. Byrappa, K.; Ohara, S.; Adschiri, T. Nanoparticles synthesis using supercritical fluid technology-towards biomedical applications. Adv. Drug Deliv. Rev. 2008, 60, 299-327. [CrossRef] [PubMed]

50. Lam, U.T.; Mammucari, R.; Suzuki, K.; Foster, N.R. Processing of Iron Oxide Nanoparticles by Supercritical Fluids. Ind. Eng. Chem. Res. 2008, 47, 599-614. [CrossRef]

51. Rachakatla, R.S.; Balivada, S.; Seo, G.-M.; Myers, C.B.; Wang, H.; Samarakoon, T.N.; Dani, R.; Pyle, M.; Kroh, F.O.; Walker, B.; et al. Attenuation of Mouse Melanoma by A/C Magnetic Field after Delivery of Bi-Magnetic Nanoparticles by Neural Progenitor Cells. ACS Nano 2010, 4, 7093-7104. [CrossRef] [PubMed]

52. Wang, H.; Covarrubias, J.; Prock, H.; Wu, X.; Wang, D.; Bossmann, S.H. Acid-Functionalized Magnetic Nanoparticle as Heterogeneous Catalysts for Biodiesel Synthesis. J. Phys. Chem. C 2015, 119, 26020-26028. [CrossRef]

53. Wang, H.; Shrestha, T.B.; Basel, M.T.; Pyle, M.; Toledo, Y.; Konecny, A.; Thapa, P.; Ikenberry, M.; Hohn, K.L.; Chikan, V.; et al. Hexagonal magnetite nanoprisms: Preparation, characterization and cellular uptake. J. Mater. Chem. B 2015, 3, 4647-4653. [CrossRef]

54. Konecny, A.P.; Covarrubias, J.; Wang, H. Magnetic Nanoparticle Design and Application in Magnetic Hyperthermia. In Magnetic Nanomaterials: Applications in Catalysis and Life Sciences; Bossmann, S.H., Wang, H., Eds.; RSC: London, UK, 2017.

55. Abayaweera, G.S.; Wang, H.; Shrestha, T.B.; Yu, J.; Angle, K.; Thapa, P.; Malalasekera, A.P.; Maurmann, L.; Troyer, D.L.; Bossmann, S.H. Synergy of iron chelators and therapeutic peptide sequences delivered via a magnetic nanocarrier. J. Funct. Biomater. 2017, 8, 23. [CrossRef]

56. Hasany, S.F.; Ahmed, I.; Rajan, J.; Rehman, A. Systematic review of the preparation techniques of iron oxide magnetic nanoparticles. Nanosci. Nanotechnol. 2012, 2, 148-158. [CrossRef]

57. Charinpanitkul, T.; Sano, N.; Muthakarn, P.; Tanthapanichakoon, W. Enhancing effect of monoolein surfactant on carbon nanoparticle synthesis by arc discharge in liquid. Mater. Res. Bull. 2009, 44, 324-327. [CrossRef]

58. Ahmad, F.; Zhou, Y. Pitfalls and Challenges in Nanotoxicology: A Case of Cobalt Ferrite $\left(\mathrm{CoFe}_{2} \mathrm{O}_{4}\right)$ Nanocomposites. Chem. Res. Toxicol. 2017, 30, 492-507. [CrossRef] [PubMed]

59. Odio, O.F.; Reguera, E. Nanostructured spinel ferrites: Synthesis, functionalization, nanomagnetism and environmental applications. In Magnetic Spinels—Synthesis, Properties and Applications; InTechOpen: London, UK, 2017; pp. 185-216.

60. Piao, Y.; Kim, J.; Na, H.B.; Kim, D.; Baek, J.S.; Ko, M.K.; Lee, J.H.; Shokouhimehr, M.; Hyeon, T. Wrap-bake-peel process for nanostructural transformation from $\beta$-FeOOH nanorods to biocompatible iron oxide nanocapsules. Nat. Mater. 2008, 7, 242. [CrossRef] [PubMed]

61. Chu, D.B.K.; Owen, J.S.; Peters, B. Nucleation and Growth Kinetics from LaMer Burst Data. J. Phys. Chem. A 2017, 121, 7511-7517. [CrossRef] [PubMed]

62. Peng, S.; Wang, C.; Xie, J.; Sun, S. Synthesis and stabilization of monodisperse Fe nanoparticles. J. Am. Chem. Soc. 2006, 128, 10676-10677. [CrossRef]

63. Peng, S.; Sun, S. Synthesis and characterization of monodisperse hollow $\mathrm{Fe}_{3} \mathrm{O}_{4}$ nanoparticles. Angew. Chem. 2007, 46, 4155-4158. [CrossRef] [PubMed]

64. Frey, N.A.; Peng, S.; Cheng, K.; Sun, S. Magnetic nanoparticles: Synthesis, functionalization, and applications in bioimaging and magnetic energy storage. Chem. Soc. Rev. 2009, 38, 2532-2542. [CrossRef] [PubMed]

65. Seo, W.S.; Lee, J.H.; Sun, X.; Suzuki, Y.; Mann, D.; Liu, Z.; Terashima, M.; Yang, P.C.; McConnell, M.V.; Nishimura, D.G. FeCo/graphitic-shell nanocrystals as advanced magnetic-resonance-imaging and near-infrared agents. Nat. Mater. 2006, 5, 971. [CrossRef]

66. Willard, M.; Kurihara, L.; Carpenter, E.; Calvin, S.; Harris, V. Chemically prepared magnetic nanoparticles. Int. Mater. Rev. 2004, 49, 125-170. [CrossRef]

67. Plank, C.; Schillinger, U.; Scherer, F.; Bergemann, C.; Rémy, J.-S.; Krötz, F.; Anton, M.; Lausier, J.; Rosenecker, J. The magnetofection method: Using magnetic force to enhance gene delivery. Biol. Chem. 2003, 384, 737-747. [CrossRef] 
68. McBain, S.C.; Yiu, H.H.; Dobson, J. Magnetic nanoparticles for gene and drug delivery. Int. J. Nanomed. 2008, $3,169$.

69. Kalantari, K.; Ahmad, M.B.; Shameli, K.; Hussein, M.Z.B.; Khandanlou, R.; Khanehzaei, H. Size-controlled synthesis of $\mathrm{Fe}_{3} \mathrm{O}_{4}$ magnetic nanoparticles in the layers of montmorillonite. J. Nanomater. 2014, 2014, 181. [CrossRef]

70. Sarkar, S.; Choudhury, P.; Dinda, S.; Das, P.K. Tailor-Made Self-Assemblies from Functionalized Amphiphiles: Diversity and Applications. Langmuir 2018, 34, 10449-10468. [CrossRef] [PubMed]

71. Sharma, V.K.; Mitra, S.; Mukhopadhyay, R. Dynamic Landscape in Self-Assembled Surfactant Aggregates. Langmuir 2019. ahead of print. [CrossRef] [PubMed]

72. Lee, K.; Lee, S.; Oh, M.C.; Ahn, B. Alkaline metal reagent-assisted synthesis of monodisperse iron oxide nanostructures. Metals 2018, 8, 107. [CrossRef]

73. Ortiz-Quinonez, J.-L.; Pal, U.; Villanueva, M.S. Structural, Magnetic, and Catalytic Evaluation of Spinel $\mathrm{Co}, \mathrm{Ni}$, and Co-Ni Ferrite Nanoparticles Fabricated by Low-Temperature Solution Combustion Process. ACS Omega 2018, 3, 14986-15001. [CrossRef]

74. Piche, D.; Tavernaro, I.; Fleddermann, J.; Lozano, J.G.; Varambhia, A.; Maguire, M.L.; Koch, M.; Ukai, T.; Hernandez Rodriguez, A.J.; Jones, L.; et al. Targeted T1 Magnetic Resonance Imaging Contrast Enhancement with Extraordinarily Small $\mathrm{CoFe}_{2} \mathrm{O}_{4}$ Nanoparticles. ACS Appl. Mater. Interfaces 2019, 11, 6724-6740. [CrossRef] [PubMed]

75. Sun, Y.; Zhang, J.; Zong, Y.; Deng, X.; Zhao, H.; Feng, J.; He, M.; Li, X.; Peng, Y.; Zheng, X. Crystalline-Amorphous Permalloy@Iron Oxide Core-Shell Nanoparticles Decorated on Graphene as High-Efficiency, Lightweight, and Hydrophobic Microwave Absorbents. ACS Appl. Mater. Interfaces 2019, 11, 6374-6383. [CrossRef]

76. Udukala, D.N. Protease Assays for Cancer Diagnostics. Ph.D. Thesis, Kansas State University, Manhattan, KS, USA, 2014.

77. Udukala, D.N.; Wang, H.; Wendel, S.O.; Malalasekera, A.P.; Samarakoon, T.N.; Yapa, A.S.; Abayaweera, G.; Basel, M.T.; Maynez, P.; Ortega, R.; et al. Early breast cancer screening using iron/iron oxide-based nanoplatforms with sub-femtomolar limits of detection. Beilstein J. Nanotechnol. 2016, 7, 364-373. [CrossRef]

78. Voelz, B.E.; Kalubowilage, M.; Bossmann, S.H.; Troyer, D.L.; Chebel, R.C.; Mendonca, L.G.D. Associations between activity of arginase or matrix metalloproteinase-8 (MMP-8) and metritis in periparturient dairy cattle. Theriogenology 2017, 97, 83-88. [CrossRef]

79. Wang, H.; Udukala, D.N.; Samarakoon, T.N.; Basel, M.T.; Kalita, M.; Abayaweera, G.; Manawadu, H.; Malalasekera, A.; Robinson, C.; Villanueva, D. Nanoplatforms for highly sensitive fluorescence detection of cancer-related proteases. Photochem. Photobiol. Sci. 2014, 13, 231-240. [CrossRef]

80. Choi, C.-J.; Dong, X.-L.; Kim, B.-K. Microstructure and magnetic properties of Fe nanoparticles synthesized by chemical vapor condensation. Mater. Trans. 2001, 42, 2046-2049. [CrossRef]

81. Goodwin, S.C.; Bittner, C.A.; Peterson, C.L.; Wong, G. Single-dose toxicity study of hepatic intra-arterial infusion of doxorubicin coupled to a novel magnetically targeted drug carrier. Toxicol. Sci. 2001, 60, 177-183. [CrossRef]

82. Steinfeld, U.; Pauli, C.; Kaltz, N.; Bergemann, C.; Lee, H.-H. T lymphocytes as potential therapeutic drug carrier for cancer treatment. Int. J. Pharm. 2006, 311, 229-236. [CrossRef] [PubMed]

83. Sunderland, C.J.; Steiert, M.; Talmadge, J.E.; Derfus, A.M.; Barry, S.E. Targeted nanoparticles for detecting and treating cancer. Drug Dev. Res. 2006, 67, 70-93. [CrossRef]

84. Lu, A.H.; Salabas, E.L.; Schüth, F. Magnetic nanoparticles: Synthesis, protection, functionalization, and application. Angew. Chem. 2007, 46, 1222-1244. [CrossRef] [PubMed]

85. Sun, C.; Lee, J.S.; Zhang, M. Magnetic nanoparticles in MR imaging and drug delivery. Adv. Drug Deliv. Rev. 2008, 60, 1252-1265. [CrossRef]

86. Yang, J.; Lee, H.; Hyung, W.; Park, S.-B.; Haam, S. Magnetic PECA nanoparticles as drug carriers for targeted delivery: Synthesis and release characteristics. J. Microencapsul. 2006, 23, 203-212. [CrossRef] [PubMed]

87. Zhou, L.; Yuan, J.; Yuan, W.; Sui, X.; Wu, S.; Li, Z.; Shen, D. Synthesis, characterization, and controllable drug release of pH-sensitive hybrid magnetic nanoparticles. J. Magn. Magn. Mater. 2009, 321, 2799-2804. [CrossRef] 
88. Zhou, L.; Yuan, J.; Yuan, W.; Zhou, M.; Wu, S.; Li, Z.; Xing, X.; Shen, D. Synthesis and characterization of multi-functional hybrid magnetite nanoparticles with biodegradability, superparamagnetism, and fluorescence. Mater. Lett. 2009, 63, 1567-1570. [CrossRef]

89. Kumar, A.; Jena, P.K.; Behera, S.; Lockey, R.F.; Mohapatra, S.; Mohapatra, S. Multifunctional magnetic nanoparticles for targeted delivery. Nanomed. Nanotechnol. Biol. Med. 2010, 6, 64-69. [CrossRef]

90. Sun, Y.; Chen, Z.-L.; Yang, X.-X.; Huang, P.; Zhou, X.-P.; Du, X.-X. Magnetic chitosan nanoparticles as a drug delivery system for targeting photodynamic therapy. Nanotechnology 2009, 20, 135102. [CrossRef] [PubMed]

91. Dougherty, T.J.; Gomer, C.J.; Henderson, B.W.; Jori, G.; Kessel, D.; Korbelik, M.; Moan, J.; Peng, Q. Photodynamic therapy. JNCI J. Natl. Cancer Inst. 1998, 90, 889-905. [CrossRef] [PubMed]

92. Jain, T.K.; Richey, J.; Strand, M.; Leslie-Pelecky, D.L.; Flask, C.A.; Labhasetwar, V. Magnetic nanoparticles with dual functional properties: Drug delivery and magnetic resonance imaging. Biomaterials 2008, 29, 4012-4021. [CrossRef] [PubMed]

93. Kohler, N.; Sun, C.; Fichtenholtz, A.; Gunn, J.; Fang, C.; Zhang, M. Methotrexate-immobilized poly (ethylene glycol) magnetic nanoparticles for MR imaging and drug delivery. Small 2006, 2, 785-792. [CrossRef] [PubMed]

94. Podaru, G.; Chikan, V. Magnetism in Nanomaterials: Heat and Force from Colloidal Magnetic Particles. In Magnetic Nanomaterials: Applications in Catalysis and Life Sciences; Bossmann, S.H., Wang, H., Eds.; Royal Society of Chemistry: London, UK, 2017; Volume 26.

95. Akbarzadeh, A.; Samiei, M.; Davaran, S. Magnetic nanoparticles: Preparation, physical properties, and applications in biomedicine. Nanoscale Res. Lett. 2012, 7, 1-13. [CrossRef] [PubMed]

96. Kolhatkar, A.G.; Jamison, A.C.; Litvinov, D.; Willson, R.C.; Lee, T.R. Tuning the Magnetic Properties of Nanoparticles. Int. J. Mol. Sciences 2013, 14, 15977-16009. [CrossRef] [PubMed]

97. El-Boubbou, K. Magnetic iron oxide nanoparticles as drug carriers: Clinical relevance. Nanomedicine 2018, 13, 953-971. [CrossRef] [PubMed]

98. Karponis, D.; Azzawi, M.; Seifalian, A. An arsenal of magnetic nanoparticles; perspectives in the treatment of cancer. Nanomedicine 2016, 11, 2215-2232. [CrossRef] [PubMed]

99. Xie, J.; Zhang, Y.; Yan, C.; Song, L.; Wen, S.; Zang, F.; Chen, G.; Ding, Q.; Yan, C.; Gu, N. High-performance PEGylated Mn-Zn ferrite nanocrystals as a passive-targeted agent for magnetically induced cancer theranostics. Biomaterials 2014, 35, 9126-9136. [CrossRef] [PubMed]

100. Lee, J.E.; Lee, N.; Kim, H.; Kim, J.; Choi, S.H.; Kim, J.H.; Kim, T.; Song, I.C.; Park, S.P.; Moon, W.K.; et al. Uniform mesoporous dye-doped silica nanoparticles decorated with multiple magnetite nanocrystals for simultaneous enhanced magnetic resonance imaging, fluorescence imaging, and drug delivery. J. Am. Chem. Soc. 2009, 132, 552-557. [CrossRef] [PubMed]

101. Yang, X.; Li, Z.; Li, M.; Ren, J.; Qu, X. Fluorescent protein capped mesoporous nanoparticles for intracellular drug delivery and imaging. Chem. A Eur. J. 2013, 19, 15378-15383. [CrossRef]

102. Hwu, J.R.; Lin, Y.S.; Josephrajan, T.; Hsu, M.-H.; Cheng, F.-Y.; Yeh, C.-S.; Su, W.-C.; Shieh, D.-B. Targeted paclitaxel by conjugation to iron oxide and gold nanoparticles. J. Am. Chem. Soc. 2008, 131, 66-68. [CrossRef]

103. Bai, Y.-Y.; Zheng, S.; Zhang, L.; Xia, K.; Gao, X.; Li, Z.-H.; Li, C.; He, N.; Ju, S. Non-invasively evaluating therapeutic response of nanorod-mediated photothermal therapy on tumor angiogenesis. J. Biomed. Nanotechnol. 2014, 10, 3351-3360. [CrossRef]

104. Jaiswal, M.K.; Pradhan, A.; Banerjee, R.; Bahadur, D. Dual pH and temperature stimuli-responsive magnetic nanohydrogels for thermo-chemotherapy. J. Nanosci. Nanotechnol. 2014, 14, 4082-4089. [CrossRef]

(C) 2019 by the authors. Licensee MDPI, Basel, Switzerland. This article is an open access article distributed under the terms and conditions of the Creative Commons Attribution (CC BY) license (http://creativecommons.org/licenses/by/4.0/). 